\title{
A BRIEF HISTORIOGRAPHY OF U.S. HEGEMONY IN THE CUBAN SUGAR INDUSTRY
}

By Justin McCollum

In July 1898 the United States entered the Cuban War for Independence, in which Cubans were fighting Spain for autonomy of the island. In December 1898, Spain capitulated to the United States and signed the Treaty of Paris, which transferred sovereignty of Cuba to the United States. The formal military occupation of Cuba by the United States began on 1 January 1899. The ensuing agreements established with Cuba gave the United States a position of hegemony on the island. This dominance manifested itself most thoroughly in Cuba's sugar industry, which acted as the backbone of its economy.

This historiographical essay maintains that the historical record of Cuba has been greatly shaped by the Cuban natural environment, specifically the island's propensity to support sugarcane. This paper will focus on the effects of the U.S. hegemony in the Cuban sugar industry; of particular interest will be the ability of the U.S. sugar hegemony to create an atmosphere that was particularly susceptible to the revolutionary movement led by Fidel Castro. The Cuban scholars analyzed in this paper highlight different historical phenomena and their relationships to Cuba's natural environment. Regardless of the specifics of the topic each scholar examines, it will become clear that Cuba's natural environment heavily influenced its history. 
The general trend of Cuban historiography accentuates the role of U.S. capitalists as they took advantage of the war-torn island, bought up cheap sugar capital, forced peasants from their land, and imposed a heightened level of capitalism on Cuban society. During the period of U.S. hegemony, Cuba witnessed the destruction of peasant communities due to the expansion of sugar plantations (latifundios), and the creation of new social classes which resulted from technological changes that barred Cuban planters access to necessary and expensive capital. Consequently, Cuba's export-oriented monoculture economy became dependent on both foreign capital and high sugar prices in the global market, and the United States used its position as both Cuba's primary capital investor and sugar consumer to leverage Cuban politics.

In the late 1960s, after Fidel Castro's revolution, Cuban scholars Ramiro Guerra Sanchez and Lester D. Langley studied the effects of Cuban sugar on the revolutionary movement and initiated what will be referred to as the "orthodox" view. They agree that the destruction of the Cuban general economy, its sugar-related capital and infrastructure, and the economic ruin of the planter class during the War for Independence necessitated imported capital to revive the country. However, they acknowledge that U.S. investors and corporations were reluctant to pour such capital into the island's sugar industry until favorable trade agreements were secured and risk was limited. ${ }^{1}$

These "favorable trade agreements" caused an immediate surge of U.S. capital into the Cuban sugar industry. The first such agreement, the Platt Amendment, essentially gave the United States carte blanche to interfere in Cuban affairs when it determined that Cuba's security, political stability, or ability to protect property was at risk. The Platt Amendment essentially allowed the U.S. to control Cuba. United States investment was accelerated by passage of the Reciprocity Treaty in 1903, which reduced tariffs on goods exchanged between the two countries-most specifically, Cuba's import tariffs (paid to the U.S.) would be credited twenty percent of the sugar it exported to the U.S. Langley argues that other than the guarantee of a sugar market, "Cuban sugar producers benefited little financially by the twenty percent pref-

\footnotetext{
${ }^{1}$ Ramiro Guerra Sanchez, Sugar and Society in the Caribbean: An Economic History of Cuban Agriculture (New Haven, 1964), 67-74, 159; Lester D. Langley, The Cuban Policy of the United States: A Brief History (New York: John Wiley and Sons, 1968), 115-152

${ }^{2}$ Langley, 137.
} 
erential duty, for the preference merely encouraged more capital investment in sugar production." 2 However, both authors agree that the law originated solely to benefit U.S. interests, as capital imported into Cuba was credited forty percent of the duty fee. Langley also notes that the U.S. rush to profit from the Cuban landscape resembled two persistent themes of U.S. frontier expansion: the paternalistic view that Cubans were incapable of governing their own country; and the notion that Cuban land was underutilized and would only achieve its full God-given potential through the influx of U.S. capital. ${ }^{3}$

Culminating this orthodox view, Guerra Sanchez argues that Cubans were pushed into virtual serfdom as they became vassals of U.S. sugar interests. The majority of Cubans' displeasure with their socioeconomic predicament resulting from the period of U.S. sugar hegemony, coupled with the long-term degradation of the Cuban environment from extensive crop harvests, allowed Cuban peasants to be easily swayed by Castro's anti-U.S. and anti-Batista rhetoric during the revolution. ${ }^{4}$

In the 1970s this orthodox view was examined, and more environmentally-related historical contingencies were exposed. Robert B. Hoernel studies the reasons why U.S. sugar barons chose eastern Cuba as the focal point of their investment. His extremely thorough investigation begins by examining the general history of the island. During initial Spanish occupation, Santiago and Havana were separated by 700 miles of thickly vegetated, thinly populated terrain that was bisected by mountain ranges, swamps, and desert-like savannahs. Consequently, the only practical communication and transport link between the two regions was the sea. But this route flowed only one-way, from Santiago (east) to Havana (west), due to the combined effects of the Northeast Trades and the Gulf Stream, which made easting along either coast impractical and unreliable until the invention of the steamship. Additionally, Havana's location near the Florida Straits made it a logical choice as the rendezvous point for Spain's annual flotillas en route to Seville. Thus, Havana's population and economy boomed, and the metropolis catalyzed western Cuba's evolution as an export-oriented agricultural region. During the last century-and-a-half

${ }^{3}$ Ibid., 132-4

${ }^{4}$ Guerra Sanchez, 67-73. 
under the Spanish crown, "western Cuba became a comparatively cosmopolitan an dynamic society facing Europe and the Untied States, while the eastern population, as a result of geography, remained isolated, homogeneous, and parochial, and it faced the Caribbean." ${ }^{5}$ The relatively isolated and undesirable land of eastern Cuba drove real estate prices down. When U.S. investors looked to initiate large-scale sugar plantations, the price was right in the east.

Hoernel also notes that the biology of sugarcane itself played an important role in the reorganization of the Cuban landscape. The plant requires milling within twenty four hours of harvesting, as evaporation and enzymatic degradation of the sucrose rapidly diminishes its sugar content. Consequently, U.S. capitalists centrally-located their enormous sugar mills ("centrales") amongst the cane fields, and sought to control cane production in the surrounding areas. Many cane farmers who previously owned their lands became tenants ("colonos") and farmed corporate land. As colonos transferred their cane to the centrales, "they lost much of their independence and became bound to the mills" and to the market price of sugar. This system gave U.S. capitalists the means to secure access to cane while transferring some of the risk to the cane farmers. ${ }^{6}$

Hoernel acknowledges that as U.S. investors gained confidence in their nation's ability to protect their investments, the scale of development in eastern Cuba surged. He argues that, partially due to the Reciprocity Treaty (1903), it was cheaper for U.S. capitalists to buy relatively undeveloped land in eastern Cuba and import new machinery than it was to buy and improve existing mills in western Cuba. The United Fruit Company, for example, bought 200,000 acres in 1902 (for two dollars per acre), and 180,000 acres in 1904 in eastern Cuba. Additionally, U.S. capitalists bought out many Cuban planters whom had previously ground their own cane using older and cheaper machinery. ${ }^{7}$ Consequently, the number of small farmers was cut in half, and the sugar latifundias quickly assumed the largest percentage of eastern Cuba's land. As a result, many small farmers were forced off their land and moved their operations either farther inland or on to mountainsides. In each instance, they

\footnotetext{
${ }^{5}$ Robert B. Hoernel, "Sugar and Social Change in Oriente, Cuba, 1898-1946," Journal of Latin American Studies 8, no. 2 (Nov., 1976), 219.

${ }^{6}$ Ibid.

${ }^{7}$ Ibid., 221.
} 
would clear existing vegetation and increase the natural pace of erosion. Also, the exodus of small farmers onto steeper land dictated the types of crops these farmers pursued. Many of these farmers turned to the stigmatized crops of the poor and oppressed-coffee and cocoa. Hoernel implies that this new social identification fostered a deep resentment of the U.S. in particular and capitalists in general that made the Castro Revolution more feasible. ${ }^{8}$

The demand for labor in eastern Cuba during the harvest ("zafra") was greater than the local population could supply. Thus, non-white immigrant workers poured in from all over the Caribbean. Hoernel argues that it was ultimately because of the new labor requirements from the U.S. expansion of the Cuban sugar industry that caused the white, landed Cuban elite to campaign for a ban on non-white immigration. Their efforts came to fruition in 1910 through Military Order No. 155. In 1913, the Cuban government even offered a five dollar stipend for every white person imported from Panama to increase the white population. Eventually, however, the demand for workers outpaced white immigration, and non-whites were permitted entry. Thus, the demographics of eastern Cuba were forever changed due to sugarcane.

It is here that Hoernel blames U.S. capitalists for the degradation of a once rich Afro-Cuban culture in eastern Cuba. The influx of zafra workers made eastern Cuba the most populous part of the island. The rise of U.S. latifundias and the extent of the population increase, a large proportion of which was alien, severely changed the region's society, culture, and economy. In no more than twenty years, a regional society of "largely self-sufficient farmers, was transformed into one of highly dependent farm laborers working for predominately foreign corporations, eating foreign-produced foods, often living in company towns, and buying from company stores." The seasonal zafra workers brought with them strange languages, religions, and customs that disrupted eastern Afro-Cuban society. When the price of sugar dropped, many workers were laid off, and native Cubans found themselves competing with immigrants for jobs. As a result, many absconded to relatively isolated and undeveloped regions in search of land upon which to squat, clear, and cultivate.

\footnotetext{
${ }^{8}$ Ibid., 229-230, 248-249.

${ }^{9}$ Ibid., 235.
} 
These actions further disturbed Cuba's natural environment and left a bitter taste of capitalism behind. ${ }^{10}$

Conversely, when the price of sugar boomed during World War I and the 1920s, largely a result of the destruction of competition from the European sugar beet industry due to the war, prosperity was to be found in all of Cuba's sugar regions. However, the rapidly-expanding population strained eastern Cuba's public services as it caused change and friction among lower socioeconomic groups. The culture that once stressed morality and individuality morphed into an increasingly impersonal and amoral way of life as eastern Cubans converted to consumerism. Additionally, the increase in population due to zafra workers was disproportionately male, which led to a situation that fostered vice, violence, rape, and prostitution (Hoernel also lists a disproportionately high level of homosexuality in eastern Cuba as a result of the zafra influx). In fact, Hoernel traces Cuba's contemporary reputation as a land of heightened promiscuity to this "cultural breakdown." 11

Jules Robert Benjamin, writing at the same time as Hoernel, generally agrees with Hoernel, but introduces several different environmentally-related historical contingencies that affected the Cuban sugar industry. Benjamin argues that because Cuba's independence came at the time when U.S. capitalists were forming large trusts, investment in the industry followed the U.S. pattern of monopolies. This model of investment allowed for a complete domination of the industry, which accelerated both the spread of poverty and the alteration of the natural Cuban landscape. ${ }^{12}$

Benjamin also agrees with Langley's and Guerra Sanchez's interpretation of the Reciprocity Treaty directly benefiting U.S. capitalists more than $\mathrm{Cu}$ bans, but notes that the Reciprocity Treaty probably would not have passed the U.S. Congress without President Theodore Roosevelt's insistence. Roosevelt's experience as a Rough Rider in Cuba's War for Independence generated a sense of personal attachment to the country. Thus, although Roosevelt generally favored agricultural protection, his connection with Cuba convinced

\footnotetext{
${ }^{10}$ Ibid., 236.

${ }^{11}$ Ibid., 237.

${ }^{12}$ Jules Robert Benjamin, The United States and Cuba: Hegemony and Dependent Development, 1880-1934 (Pittsburg: University of Pittsburg Press, 1974), 8.
} 
him that it was a special case, and he supported reciprocity. Benjamin notes that without the Reciprocity Treaty, Cubans would not have had a market for sugar, as the duty-free sugar from Hawaii, the Philippines, and Puerto Rico would have out-competed Cuban sugar.

Additionally, Benjamin argues that the continued U.S. presence in Cuba created resentment among most elements of the post-independence generation of Cubans, and their frustrations were taken out on a succession of $\mathrm{Cu}-$ ban presidents. He explains that because "each Cuban president had to make his peace with the United States, none of them was able to avoid for very long the accusation of having betrayed the nation. " Hence, pre-Castro Cuban governments never achieved legitimacy, and were easy targets for disenchanted, revolutionary-minded Cubans.

Finally, Benjamin argues that because of sugarcane's seasonal nature, the Cuban economy ran on credit, which made banks even more influential institutions than usual. As the European sugar beet industry recovered after WWI and the price of sugar dropped, a sugar crash hit Cuba from 1920-1921. The low price of sugar caused inflation to soar, and U.S. banks capitalized on the situation. Fearing economic disaster, U.S. politicians pushed a banking bill through the Cuban Congress, the terms of which most Cuban banks could not meet. As a result, the largest banks in Cuba folded, and only four domestic banks survived. With the sole exception of the Royal Bank of Canada, the vacuum was filled by U.S. banks. In the spirit of Cold War historians, Benjamin ends by implying that such U.S. domination of Cuba, springing from the sugar industry, proffered a negative view of capitalism throughout the island that led to Cuba's socialist movement and, ultimately, the Cuban Communist Party.

The end of the Cold War prompted a prodigious amount of publications on the Cuban sugar industry. Again, scholars pointed to environmentally-related historical contingencies that severely impacted Cuba's lively history. Jorge F. Perez-Lopez agrees with previous scholars that the plight of Cubans

\footnotetext{
${ }^{13}$ Ibid., 10-12.

${ }^{14}$ Ibid., 6.

${ }^{15} \mathrm{Ibid}$

${ }^{16}$ Ibid., 9,14-17

${ }^{17}$ Ibid., 62-63.
} 
due to the U.S. sugar hegemony fueled Castro's revolution and provided it with thousands of peasant farmers from eastern Cuba. However, he argues that even though the U.S. essentially abandoned the industry during the Great Depression, the "Cubanization" of the economy did not culminate until after World War II-Cuba's last real sugar boom. Thus, not only did the Cubans miss out on an exorbitant amount of profits, they remained dependent on U.S. capital, which prolonged the sense of dependency Cubans had felt since 1898. Perez-Lopez argues that this frustration was coupled with a perception of U.S.-stimulated inequities that caused a serious urban-rural divide in $\mathrm{Cu}$ ban society on which Castro capitalized. ${ }^{18}$

In a beautiful display of microhistory, Mark Smith presents a case study of the U.S.-owned Central Manati, nearly four hundred miles east of Havana. He suggests that the data from this central can be generally applied to eastern Cuba to better understand its early twentieth-century sugar industry. His study of bateys, villages and towns created for, or directly sustained by, the sugar industry, is fascinating. The scope of bateys were enormous-they contained living quarters for several thousand workers "who would be employed in and around the mill. Plans [also] called for stores, restaurants, a post office, hospital, theater, and school, all completed within a few years." ${ }^{19}$ He stresses that the majority of resources used to construct bateys came from the surrounding Cuban landscape. Palm trees were utilized for thatched-roof huts, cedar and mahogany were all harvested for more durable structures, and nearby forests were decimated of trees so that railroad ties could be obtained. ${ }^{20}$

Smith also argues that U.S. sugar hegemony changed the traditional $\mathrm{Cu}-$ ban land tenure system so that the corporate acquisition of large tracts of land became possible. During the Spanish era, inherited land was held in common by various beneficiaries. Each inheritor held a proportion of the overall ownership. Thus, large tracts of land became subdivided between many family members. Cuban law did not allow this land to be sold unless all owners unanimously voted in favor of a sale. The rarity of such agreement was problematic for land-hungry sugar barons, so the U.S. military stepped in. Military Order

${ }^{18}$ Jorge F. Perez-Lopez, The Economics of Cuban Sugar (Pittsburg: University of Pittsburg Press, 1991), 7-9.

${ }^{19}$ Mark Smith, "The Political Economy of Sugar Production and the Environment of Eastern Cuba, 1898-1923," Environmental History Review 19, no. 4 (Winter, 1995), 42.

${ }^{20}$ Ibid., 38-43. 
Number 62 divided the communal estates into privately-owned tracts which could be freely bought and sold. The sugar corporations took full advantage and bought up huge amounts of land. ${ }^{21}$

Another reason behind U.S. sugar hegemony, argues Richard P. Tucker, is a shift in consumer tastes. Perhaps reflecting racial undertones of the era, people in industrialized countries began to prefer highly refined white sugar. In order to produce such sugar, sugar refiners were forced to "adopt the fundamental [and capital-intensive] changes that were appearing in sugar refining technology, and this transformed the scale and quality of operations." ${ }^{22}$ If consumer taste did not shift, then Cubans would have likely been able to rebuild their industry without (as much) U.S. capital, and the U.S. might never have gained a position of hegemony in the Cuban sugar industry.

Smith also focuses on the sheer destruction of the Cuban natural environment as a result of U.S. sugar hegemony. He repeatedly laments on instances where U.S. capitalists slashed and burned forests to plant more cane. Sugar tycoons preferred dense forest lands for cane farming because the constant breakdown of plant matter provided the soil with rich nutrients that resulted in faster growing cane. Ultimately, the once vast and seemingly impenetrable forests of Cuba became marginalized and only remained on various hillside patches. ${ }^{23}$

Alan Dye unearths another ecologically-significant factor of Cuban sugar production. "Ratoons" were plants that had sprouted from previously harvested cane. Cane, being a perennial crop, will grow throughout the year. Thus, it is possible to harvest ratoons in subsequent years, which saves labor by avoiding the need to plant a whole new crop. Generally, ratoons are only harvested in extremely fertile soils, the best of which usually allowed for three consecutive (annual) crops to be harvested from the original plant. In Cuba, however, soil fertility allowed for as many as thirty consecutive harvests to occur before replanting. U.S. sugar tycoons saved a tremendous amount of capital by keeping labor costs down, and this capital could be reinvested in the form of adding more Cuban land to their operations. ${ }^{24}$

${ }^{21}$ Ibid., 35

${ }^{22}$ Richard P. Tucker, Insatiable Appetite: The United States and the Ecological Degradation of the Tropical World (Berkeley: University of California Press, 2000), 35-37.

${ }^{23}$ Ibid., 43-46. 
An added ecological determinate in the success of the Cuban sugar industry came in the form of a plant virus - mosaic disease. Stuart McCook argues that although mosaic disease was virtually ignored during the era of U.S. sugar hegemony, it devastated the industry's future on the island. Researchers discovered mosaic in Cuban sugarcane during the World War I sugar boom, but as immediate losses from the virus are minimal, it was disregarded. The mosaic virus does not immediately kill the Crystalina cane, the predominant variety cultivated in Cuba. However, mosaic does make the cane more susceptible to death from secondary causes, such as more readily succumbing to drought or easily uprooting when exposed to high winds (due to a weaker root system). Finally, mosaic stunted the growth of Crystalina cane and required frequent replanting due to deterioration of the plant. The economic factor of smaller crops and increased labor translated to higher operational costs which proved too much for Cubans to effectively surmount once U.S. sugar hegemony ended. Thus, Cuban production faltered, the economy deteriorated, and a large class of poverty-stricken farmers became ripe for Castro's picking.

This fascinating historiography exposes the importance of environmentally-related historical contingencies in Cuban history. United States hegemony in Cuban sugar undoubtedly put a permanent mark on the island's history, and will likely continue to shape its future development. However, although most historians brushed over the effects that sugar had on the development of Cuban railroads, none gave the issue an appropriate amount of attention. As the great environmental historian Willaim Cronon portrays in his work, Nature's Metropolis: Chicago and the Great West, railroads have the potential to provoke monumental change of an area's landscape, and thus its history. A further area of study lacking in this historiography is the relatively sparsely populated southern coast of Cuba around the port of Trinidad. Located in the middle of the island, this region was undoubtedly influenced by both Cuba's eastern and western sugar culture, and played a hefty role in the industry. A thorough assessment of these topics would sweeten the history of Cuba.

${ }^{24}$ Alan Dye, Cuban Sugar in the Age of Mass Production: Technology and the Economics of the Sugar Central, 1899-1929 (Stanford: Stanford University Press, 1998), 156-162.

${ }^{25}$ Stuart McCook, States of Nature: Science, Agriculture, and Environment in the Spanish Caribbean, 1760-1940 (Austin: University of Austin Press, 2002), 98-102. 
Benjamin, Jules Robert. The United States and Cuba: Hegemony and Dependent Development, 1880-1934. Pittsburgh: University of Pittsburgh Press, 1974.

Dye, Alan. Cuban Sugar in the Age of Mass Production: Technology and the Economics of the Sugar Central, 1899-1929. Stanford: Stanford University Press, 1998.

Guerra Sanchez, Ramiro. Sugar and Society in the Caribbean: An Economic History of Cuban Agriculture. New Haven: Yale University Press, 1964.

Hoernel, Robert B. "Sugar and Social Change in Oriente, Cuba, 1898-1946." Journal of Latin American Studies 8, no. 2 (Nov., 1976), 215-249.

Langley, Lester D. The Cuban Policy of the United States: A Brief History. New York: John Wiley and Sons, 1968.

McCook, Stuart. States of Nature: Science, Agriculture, and Environment in the Spanish Caribbean, 1760-1940. Austin: University of Austin Press, 2002.

Perez-Lopez, Jorge F. The Economics of Cuban Sugar. Pittsburgh: University of Pittsburgh Press, 1991.

Smith, Mark. "The Political Economy of Sugar Production and the Environment of Eastern Cuba, 1898-1923.” Environmental History Review 19, no. 4 (Winter, 1995), 31-48.

Tucker, Richard P. Insatiable Appetite: The United States and the Ecological Degradation of the Tropical World. Berkeley: University of California Press, 2000. 